\title{
Historical survey of research related to fire management and fauna conservation in the world and in Brazil
}

\author{
Christian Niel Berlinck ${ }^{1 *}$, Luanne Helena Augusto Lima ${ }^{1}$ \& Elildo Alves Ribeiro de Carvalho Junior ${ }^{1}$ \\ ${ }^{1}$ Instituto Chico Mendes de Conservação da Biodiversidade, Centro Nacional de Pesquisa e Conservação de \\ Mamiferos Terrestres, Estrada Municipal Hisaichi Takebayashi, Usina, 12.952-011, Atibaia, SP, Brasil. \\ *Corresponding author: christian.berlinck@icmbio.gov.br
}

BERLINCK, C.N., LIMA, L.H.A., CARVALHO JUNIOR, A.R. Historical survey of research related to fire management and fauna conservation in the world and in Brazil. Biota Neotropica 21(3): e20201144. https://doi.org/10.1590/1676-0611-BN-2020-1144

\begin{abstract}
Fire is a key ecological factor affecting biodiversity structure and composition. Fires' effects on biodiversity can be beneficial or harmful depending on how, where, when, and why they occur. The impacts of fire on fauna vary according to species ecology and the fire regime. To understand the research effort relating fire, fauna, and mammals, we surveyed papers published in World and in Brazil. Only 5\% of the publications between 1970 and 2019 with fire subject dealt with fauna and 0.5\% with mammal. For Brazil, we obtained 7\% of papers for fauna and 3\% for mammal. The Brazilian Biome with more papers was Cerrado, followed by Atlantic Forest, Amazon, Pampas, Caatinga and Pantanal. The United States of America and Australia stand out as protagonists in their continents with the largest papers number. The volume of research is related to investment in Research and Development and to occurrence of fires. The slope of temporal trend shows the terms related to wildfire have more papers than prescribed burn and there is less interest in fauna and mammal research. It is necessary to form research groups with these themes as research lines and intensify research relating fire ecology and mammals. There is yet no unified understanding of how fire may influence animal diversity and how it influences the vegetative structure and subsequently the resources which wildlife rely on. We consider this information is essential to establish efficient conservation policies.
\end{abstract}

Keywords: Scientometric Evaluation; Bushfire; Forest Fire; Controlled Burn; Mammal; Fire Ecology.

\section{Levantamento de artigos científicos relacionados à gestão do fogo e a conservação da fauna no mundo e no Brasil}

Resumo: O fogo é um fator ecológico que pode determinar os padrões de diversidade, estrutura e composição da biodiversidade. Assim, o fogo pode ser favorável ou prejudicial, dependendo de como, onde, quando e porquê ocorre. Os impactos do fogo na fauna variam de acordo com a ecologia das espécies e o regime de fogo. Levantamos a quantidade de artigos publicados no mundo e no Brasil para entender o esforço de pesquisa que relaciona fogo, fauna e mamíferos. Apenas 5\% das publicações entre 1970 e 2019 com o assunto fogo tratam de fauna e 0,5\% de mamíferos. Para o Brasil, obtivemos 7\% dos artigos para fauna e 3\% para mamíferos. O bioma brasileiro com mais artigos foi o Cerrado, seguido por Mata Atlântica, Amazônia, Pampa, Caatinga e Pantanal. Os países que se destacam como protagonistas em seus continentes, com maior número de publicações, são Estados Unidos da América e Austrália. O volume de pesquisas está relacionado aos investimentos em pesquisa e desenvolvimento e à ocorrência de incêndios florestais. A regressão linear demonstra que os termos relacionados a incêndios florestais têm mais publicações do que os relacionados a queimas prescritas e há menos interesse em pesquisas relacionadas a fauna e a mamíferos. Diante disso, acreditamos ser necessário formar grupos de pesquisa nesses temas e intensificar os estudos relacionando ecologia do fogo e mamíferos. Ainda não existe um entendimento único sobre a influência do fogo na diversidade de animais e na estrutura da vegetação e, subsequentemente, nos recursos dos quais a vida selvagem depende. Consideramos que essas informações são essenciais para estabelecer políticas públicas de conservação mais eficientes.

Palavras-chave: Cienciometria; Incêndio Florestal; Queimada; Mamíferos; Ecologia do Fogo. 


\section{Introduction}

Wildfire is a major driver of ecosystem structure and function (Bowman et al. 2009; He et al. 2019) and is a key determinant of diversity, structure and composition of biological communities (Whelan 1997). The effects of fire on vegetation are well known, but the same cannot be said about its effect on fauna (Briani \& Vieira 2006; Frizzo et al. 2011, Kelly et al. 2012, Arruda et al. 2018). This lack of information hinders assessments for the use of fire as a tool for management of natural areas (Mistry 1998b).

Fire occurs on all continents, caused either by natural factors such as volcanism and lightning, or by anthropogenic causes. Hardesty et al. (2005) assigned the world's ecosystems into three categories according to their associations with fire: fire-dependent, fire-sensitive, and fire-independent. In Brazil, fire occurs in all its six biomes. Pivello (2011) classified the Cerrado (Brazilian Savanna), Pampa (Southern Brazilian Grassland) and Pantanal (Brazilian Wetland) as fire-dependent because they are fire-prone ecosystems; the Amazon and Atlantic Forests as fire-sensitive, and the Caatinga (Semi-Arid Scrub Forest) as fire-independent. However, even non-pyrophyte environments nowadays suffer from frequent and intense wildfires due to climate change (Jolly et al. 2015) and other factors such as deforestation and habitat degradation, which also modify the fire regime and enhance its negative impacts (Brando et al. 2020).

Fire effects may be beneficial or detrimental depending on the circumstances. Fires can lead to habitat and biodiversity loss in firesensitive ecosystems, nevertheless fire is necessary to maintain native species, habitats and landscape in fire-prone ecosystems (Myers 2006). Species responses to fires vary depending on the ecology of each species and the fire regime, especially frequency, intensity, season, and size of the burned area (He et al. 2019). Fire impacts can be positive or negative, and direct or indirect (Smith 2000, Yarnell et al. 2007, Frizzo et al. 2011) and are linked to specific microhabitat preferences. In addition, functional traits of fauna can be used to predict species-specific responses to fire (Santos et al. 2016) and can be used as bioindicators of ecological disturbance (Arruda et al. 2020).

Prescribed burn can be defined as any supervised fire conducted to meet specific management objectives (Santín \& Doerr 2016), contrasting to wildfires, which are unplanned (Morgan et al. 2020), tend to affect large areas, and are usually detrimental to people, crops, infrastructure, and the environment. Land managers frequently use prescribed burn to reduce the extent of wildfires and to benefit biodiversity, but evidence supporting the positive effects of prescribed burn for biodiversity are mixed (Pastro et al. 2011, Harper et al. 2018).

In general, the dramatic character of wildfires has contributed to a societal feeling of fear toward fires, which has prevailed even among researchers, which tend to emphasize the negative effects of wildfires on biodiversity in detriment of alternative perspectives, such as the view of fire as a natural and beneficial component of ecosystem dynamics (Komarek 1969, Batista et al. 2018, Duringan et al. 2020). However, assessments of fire impacts must consider not only wildfires but also natural fires, prescribed burns, and fire regimes, since species are adapted not to fire, but to regimes (Smith 2000, Keely et al. 2011). A better understanding of the effects of different fire regimes on biodiversity and ecosystem function is fundamental to establish sound public policies for natural resource management (Durigan \& Rattter 2016).

Biodiversity is essential to maintain Ecosystem Services (ES) (Cardinale et al. 2012), and mammals are particularly important providers of ES as they comprise a highly diversified group that play key and disproportionate roles in ecosystems (Davidson et al. 2012, Sarasola et al. 2016), from pollination (Ratto et al. 2018) and seed dispersal (Torres et al. 2020) to top-down population control by predators (Ripple et al. 2014) and soil engineering (Villarreal et al. 2008, Davidson et al. 2012, Villar et al. 2020).

In this study, we conducted a scientometric evaluation of papers relating wildfire and prescribed burn to fauna in general and mammals in particular. More specifically, we evaluate the spatial distribution and temporal trends of research relating fires to wildlife and assess the relative importance of a range of different terms in fire research. In addition, we spotlight fire research in Brazil. Finally, we use the assembled information to identify gaps and suggest priorities for future research and public policy.

\section{Material and Methods}

\section{Literature search}

For the selection of database were consulted Elsevier Scopus database (www.scopus.com) and Web of Science Core Collection database (www.isiknowledge.com) in 2020 March, but we used only Elsevier Scopus database. The search was restricted to articles and reviews, using the following expressions in title, abstract and keywords: wildfire or bushfire or "forest fire"; (wildfire or bushfire or "forest fire") and (animal* or fauna); (wildfire or bushfire or "forest fire") and mammal*; "prescribed burn*" or "prescribed fire"; "prescribed burn*" or "prescribed fire" and (animal* or fauna); "prescribed burn*" or "prescribed fire" and mammal*.

\section{Geographical distribution of studies}

The search for papers published between 1945 and 2019 used the "Analyze Search Results" and "Documents by Country or Territory" tools available in the Elsevier Scopus database to compare representativeness of different continents and countries in published literature.

We also relate the number of papers to the number of Moderate Resolution Imaging Spectroradiometer (MODIS) sensors hotspots (INPE 2020) by countries. MODIS Sensors is the most operational and systematic set of data available and produced for a global comparison. Medians and quartiles of number of hotspots by continent and country, and the boxplot graph, were obtained by means of the R Software.

The data available by UNESCO (2020) was used to relate resources spending in Research and Development (R\&D) and number of papers published in each country.

\section{Temporal trends in publications}

We used Elsevier Scopus database to search publications from 1970 to 2019 to assess temporal trends in fire research. The Excel program was used to perform linear regressions to evaluate the scientific production over time.

\section{Fire research in Brazil}

The search for Brazil was restricted to articles and reviews, using the following expressions in the title, abstract and keywords: brazil* and (wildfire or bushfire or "forest fire"); brazil* and (wildfire or bushfire or 
"forest fire") and (animal* or fauna); brazil* and (wildfire or bushfire or "forest fire") and mammal*; brazil* and ("prescribed burn*" or "prescribed fire"), brazil* and "prescribed burn*" or "prescribed fire" and (animal* or fauna); brazil* and "prescribed burn*" or "prescribed fire" and mammal*.

In addition, we used the Scientific Electronic Library Online database (https://scielo.org/), a Brazilian database. The search was conducted in March 2020 and considered publications from 1909 to 2019. The search was restricted to articles using the following expressions in the topics using terms in Portuguese: incêndios florestais or incêndio florestal (wildfire); incêndio florestal or incêndios florestais and fauna (wildfire and fauna); incêndio florestal or incêndios florestais and mamífero* (wildfire and mammal); queimada or fogo (burn or fire); queimada or fogo and fauna (burn or fire and fauna); queimada or fogo and mamífero* (burn or fire and mammal); queima prescrita (prescribed burn); queima controlada or manejo do fogo (control burn or fire management); queima controlada or manejo do fogo and fauna (control burn or fire management and fauna); queima controlada or manejo do fogo and mamífero* (control burn or fire management and mammal). We agglutinate the search incêndio florestal, queimada or fogo (wildfire, burn or fire) in Fire, and queima prescrita, queima controlada or manejo do fogo (prescribed burn, control burn or fire management) in Prescribed Burn.

To analyze the number of papers by Brazilian biomes, the search carried out in Elsevier Scopus database between 1970 e 2019, was restricted to articles and reviews, using the following expressions in title, abstract and keywords: brazil* and (cerrado or savanna) fire*; brazil* and (cerrado or savanna) fire* and (animal* or fauna); brazil* and (cerrado or savanna) fire* and mammal*; "atlantic forest*" fire*, atlantic forest* fire* and (animal* or fauna); atlantic forest* fire* and mammal*; "amazon forest*" fire*; amazon forest* fire* and (animal* or fauna); amazon forest* fire* and mammal*; caatinga fire*; caatinga fire* and (animal or fauna); caatinga fire* and mammal*; ("campos sulinos" or pampas) fire*; ("campos sulinos" or pampas) fire* and (animal* or fauna); ("campos sulinos" or pampas) fire* and mammal*; (pantanal or "south america" wetland*) fire*; (pantanal or "south america" wetland*) fire* and (animal* or fauna); (pantanal or "south america" wetland*) fire* and mammal*. We agglutinated wildfire, bushfire and forest fire in Wildfire, prescribed burn and prescribed fire in Prescribed Burn, and animal and fauna in Fauna, as this research concepts were used for the same purpose.

We used the number of MODIS's hotspots (INPE 2020) by Brazilian biomes to related to number of papers.

\section{Results}

\section{Literature search}

Scopus returned approximately $20 \%$ more publications in most search terms than Web of Science Core Collection, so we restrict our analysis to this dataset. The search returned 35,133 papers published between 1945 and 2019 involving Wildfire and Prescribed Burn, of which 1,828 were related to Fauna and 544 to Mammal. Most papers were related to wildfires $(84 \%)$, with fewer papers investigating Prescribed Burn (16\%) (Figure 1A).

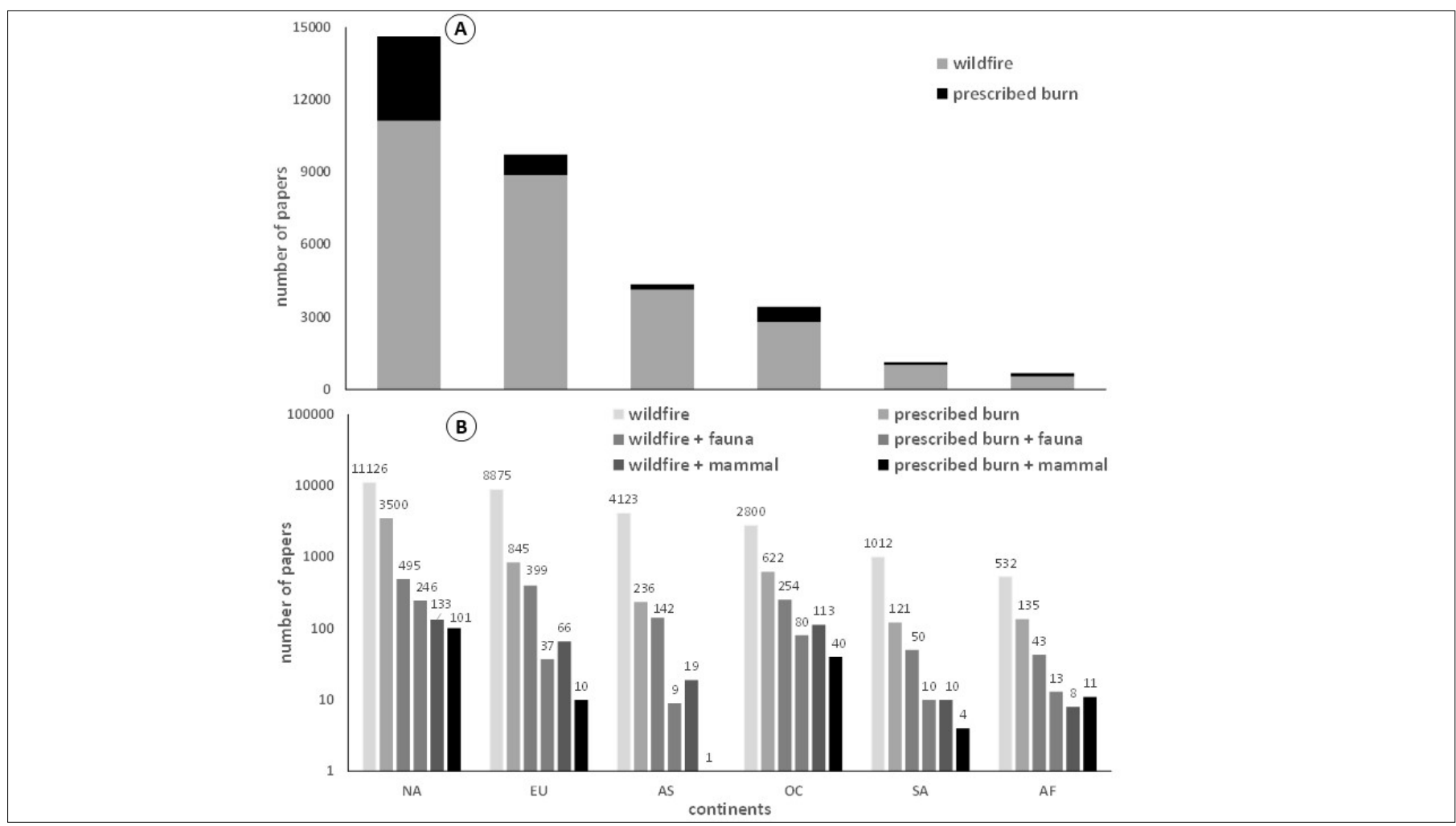

Figure 1. Number of papers on Wildfire plus Prescribed Burn (A) and number of papers for different search terms demonstrated on a Log scale (B) by continents (AF: Africa, AS: Asia, EU: Europe, NA: North America, OC: Oceania, SA: South America) 
The oldest papers found in our search date from 1894 and were published in France and in the USA. Both papers deal with political issues and impacts on the economy and human lives, without ecological issues (Fisher 1894, Anonymous 1894). The first papers on Prescribed Burn only appeared 70 years later. Both papers were published in Australia: one discusses prescribed burn as a preventive action against wildfires, without discussing conservation (McArthur 1966), while the other discusses the positive and negative effects of prescribed burning and wildfire for vegetation recovery and recruitment (Henry \& Florence 1966).

\section{Geographical distribution of studies}

Most studies were conducted in North America (42\%), followed by Europe, Asia, Oceania, South America, and Africa (28\%, 12\%, 10\% $3 \%$ and $2 \%$ respectively), three percent of papers lacked location data. The predominance of North America was observed for all search terms, but Europe was almost as important for search terms Wildfire, Wildfire + Fauna, and Prescribed Burn and Oceania for prescribed burn terms searched (Figure 1B).

In most continents there are countries predominating in search returns, with South Africa (ZAF), China (CHN), Spain (ESP), the United States of America (USA), Australia (AUS) and Brazil (BRA) leading fire research in their respective continents (Table 1). Nevertheless, there are huge differences between leading countries from different continents in the number of papers. For example, Brazil is the leading country in South America but lags far behind the USA, publishing the equivalent to $6 \%$ and $2 \%$ of USA publications on Wildfire and Prescribed Burn respectively.

The largest investors in Research and Development $(R \& D)$ are also top publishers (Figure 2). USA and CHN are the major R\&D spenders in the world and dominate publications in their continents. AUS is the $13^{\text {th }}$ largest global spender in R\&D and responds for more than $94 \%$ of publications in Oceania. BRA is the only South American country listed among the 15 largest R\&D investors and is the top publisher in the continent. Finally, ZFA is the top R\&D investor in the African continent (UNESCO 2020).

The occurrence of fires may explain the distribution of fire research among countries at the global or continental level. Figure 3 compares continents and their leading publishing countries in relation to their historical average number of MODIS hotspots. Leading publishers either have the largest number of hotspots in their continents (CHN, USA, AUS and BRA) or are in the top quartile of their continents (ZAF and ESP).

\section{Temporal trends in publications}

There were more search returns related to Wildfire (82\%) than to Prescribed Burn (18\%) in the 26,748 papers found between 1970 and 2019 (Figure 4A). A minor proportion of these papers related Fauna to Wildfire or Prescribed Burn (Figure 4B). We found 1,078 papers relating Wildfire to Fauna and 286 relating it to Mammal (Figure 4B, 4C). We found 371 papers relating Prescribed Burn to Fauna and 166 relating it to Mammal (Figure 4B, 4C). The first paper on this subject was published in the USA in the 1980s. We also found that the proportion of publications relating fires to fauna in general or to mammals in particular are insignificant: only $5 \%$ of Wildfire and $7 \%$ of Prescribed Burn papers were related to Fauna, and 1\% of Wildfire and 3\% of Prescribed Burn papers were related to mammals.

Our results show the increasing publication rates over the past 20 years (Figure 5A, 5B). We observed a significant $(\mathrm{p}<0.05)$ growth in publication rates for all terms except Prescribed Burn + Mammal with different growth rates among each search term.

\section{Fire research in Brazil}

We found 487 papers from Brazil, published between 1970 and 2019 and it matches $2 \%$ of all papers from the world. Eighty-eight percent of these belonged to the Wildfire category and only $12 \%$ to Prescribed Burn (Figure 4D), reflecting a pattern found at a global scale. We found few papers relating Fauna and Mammal with Wildfire or Prescribed Burn (Figure 4E, 4F).

The first Brazilian publications referring to Wildfire are from the 1980s and relate them to gas emissions (Leslie 1981; Kirchhoff \& Marinho 1989), deforestation-pasture-fires (Uhl \& Buschbacher 1985), and national legislation (Anonymous 1989). Apart from a brief mention to Prescribed Burn by Leslie (1981), the subject only started to appear regularly from the 1990s onward. Noteworthy papers include Pivello \& Coutinho (1992) and Prins et al. (1998) on gas emissions and nutrients; Miranda et al. (1993) on soil and air temperature variation; Mistry (1998a) on lichens as bioindicators; Pivello \& Norton (1996) on modeling software and Vieira (1999) on impacts of fire on small mammal in Cerrado.

We obtained 31 papers on Wildfire + Fauna in Brazil and nine on Wildfire + Mammal, while for Prescribed Burn + Fauna and Prescribed Burn + Mammal had four papers each, amounting to than $10 \%$ of total publications found from Brazil (Figure 4E, 4F).

The search in the Scielo database returned 124 papers about Wildfire, six on Wildfire + Fauna, three on Wildfire + Mammal and

Table 1. Countries accounting for most published fire research by continent (AF: Africa, AS: Asia, EU: Europe, NA: North America, OC: Oceania, SA: South America) for different search terms

\begin{tabular}{|c|c|c|c|c|c|c|c|c|c|c|c|c|}
\hline \multirow[b]{2}{*}{ Continents } & \multicolumn{2}{|c|}{ Wildfire } & \multicolumn{2}{|c|}{ Wildfire + Fauna } & \multicolumn{2}{|c|}{$\begin{array}{l}\text { Wildfire + } \\
\text { Mammal }\end{array}$} & \multicolumn{2}{|c|}{ Prescribed Burn } & \multicolumn{2}{|c|}{$\begin{array}{l}\text { Prescribed Burn } \\
+ \text { Fauna }\end{array}$} & \multicolumn{2}{|c|}{$\begin{array}{l}\text { Prescribed Burn } \\
+ \text { Mammal }\end{array}$} \\
\hline & Countries & $\%$ & Countries & $\%$ & Countries & $\%$ & Countries & $\%$ & Countries & $\%$ & Countries & $\%$ \\
\hline AS & $\mathrm{CHN}$ & 30 & $\mathrm{CHN}$ & 18 & JPN & 16 & $\mathrm{CHN}$ & 41 & $\mathrm{CHN}$ & 56 & IND & 100 \\
\hline EU & ESP & 20 & GBR & 17 & ESP & 21 & ESP & 21 & SWE & 22 & $*$ & $*$ \\
\hline SA & BRA & 53 & BRA & 72 & BRA & 80 & BRA & 58 & ARG & 50 & BRA & 100 \\
\hline
\end{tabular}

* no dominance, ARG: Argentina, AUS: Australia, BRA: Brazil, CHN: China, ESP: Spain, GBR: United Kingdom, IND: India, JPN: Japan, KEN: Kenya, SWE: Sweden, USA: United States of America, ZAF: South Africa 


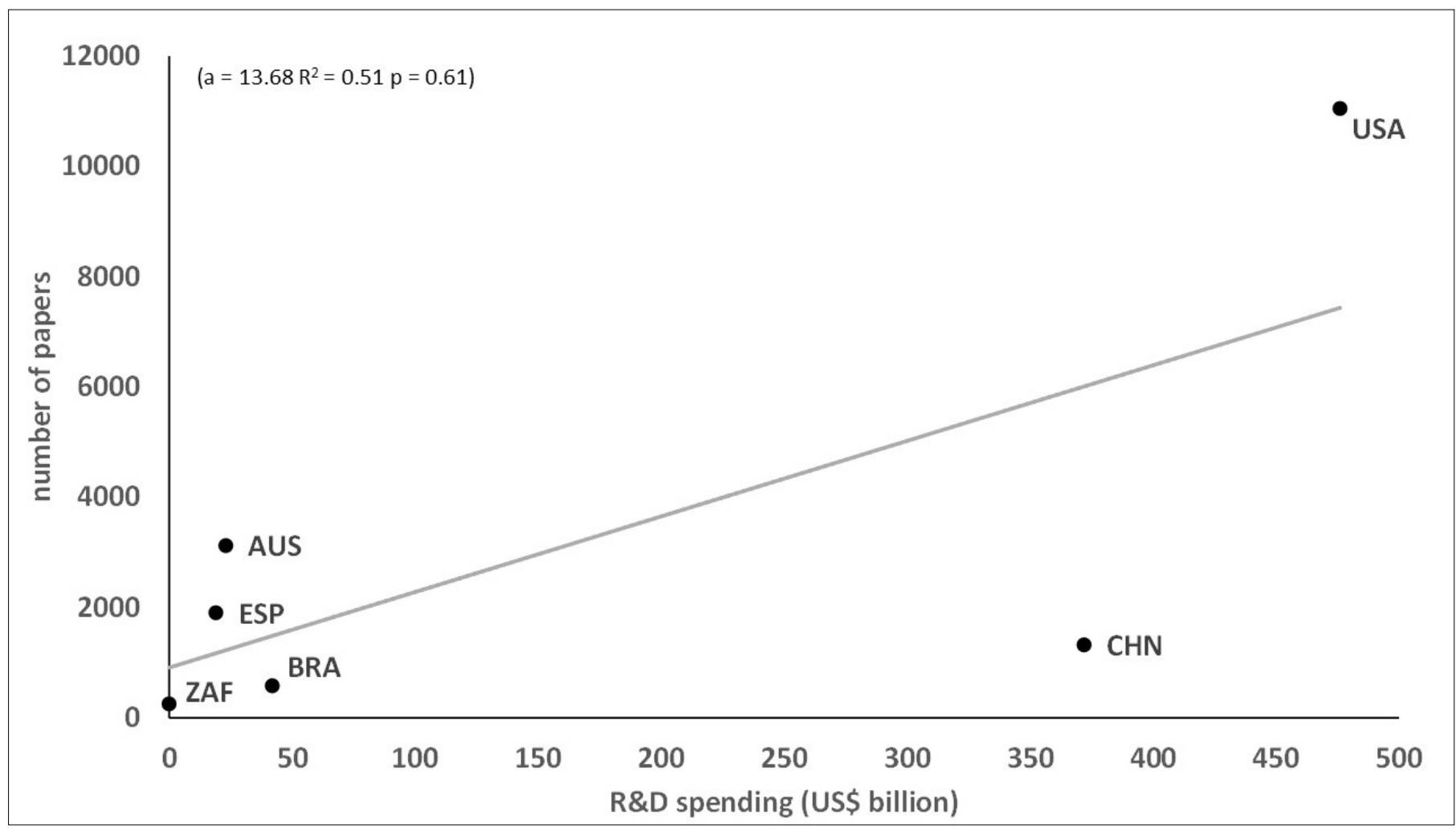

Figure 2. Number of papers published related to resources spending in Research and Development by countries (AUS: Australia, BRA: Brazil, CHN: China, ESP: Spain, USA: United States of America, ZAF: South Africa). (a: slope, $\mathrm{R}^{2}$ : coefficient of determination, p: significance probability). The degree of freedom is one for linear regression

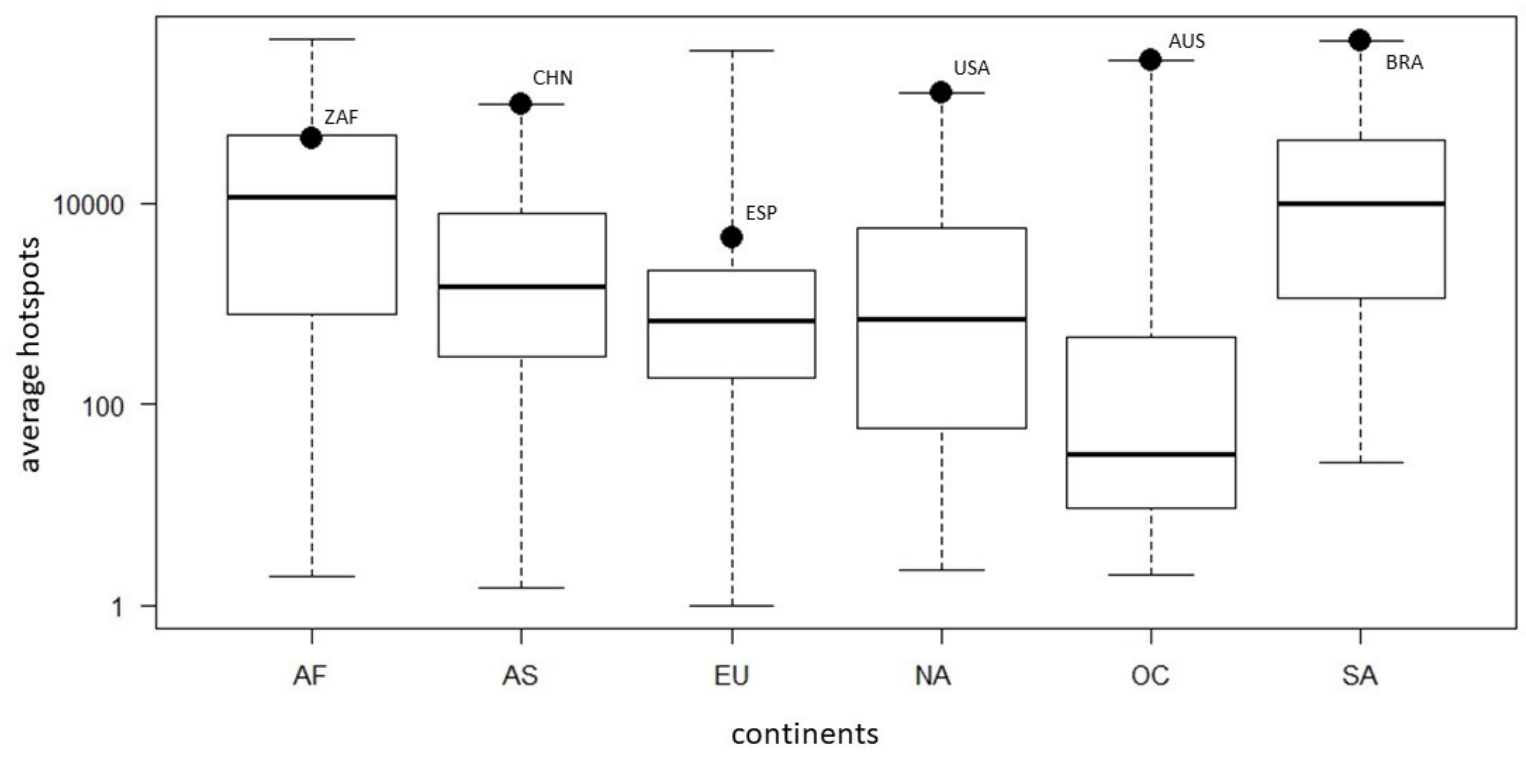

Figure 3. Boxplot of the average number of MODIS hotspots between 2002 and 2019 by continents demonstrated on a Log scale (AF: Africa, AS: Asia, EU: Europe, NA North America, OC: Oceania, SA: South America), highlighting the countries in black points (AUS: Australia, BRA: Brazil, CHN: China, ESP: Spain, USA: United States of America, ZAF: South Africa). Middle line represents the median, the rectangle extends the first and third quartile range, and whiskers extend to the minimum and maximum value

six on Prescribed Burn. No papers about Prescribed Burn + Fauna and Prescribed Burn + Mammal were found. Even in Portuguese, in the last 100 years, the number of papers is very low.

We found a positive temporal relationship with the number of published papers for Wildfire Brazil (Figure 5C), Wildfire Brazil + Fauna and Wildfire Brazil + Mammal (Figure 5D), although the relationship was weak for the later. There was no significant temporal trend for any of the searched terms for Prescribed Burn Brazil (Figure 5D).

Considering the average number of hotspots per $\mathrm{km}^{2}$ by Biome between the years 2002 and 2019, Pantanal had the highest average, 

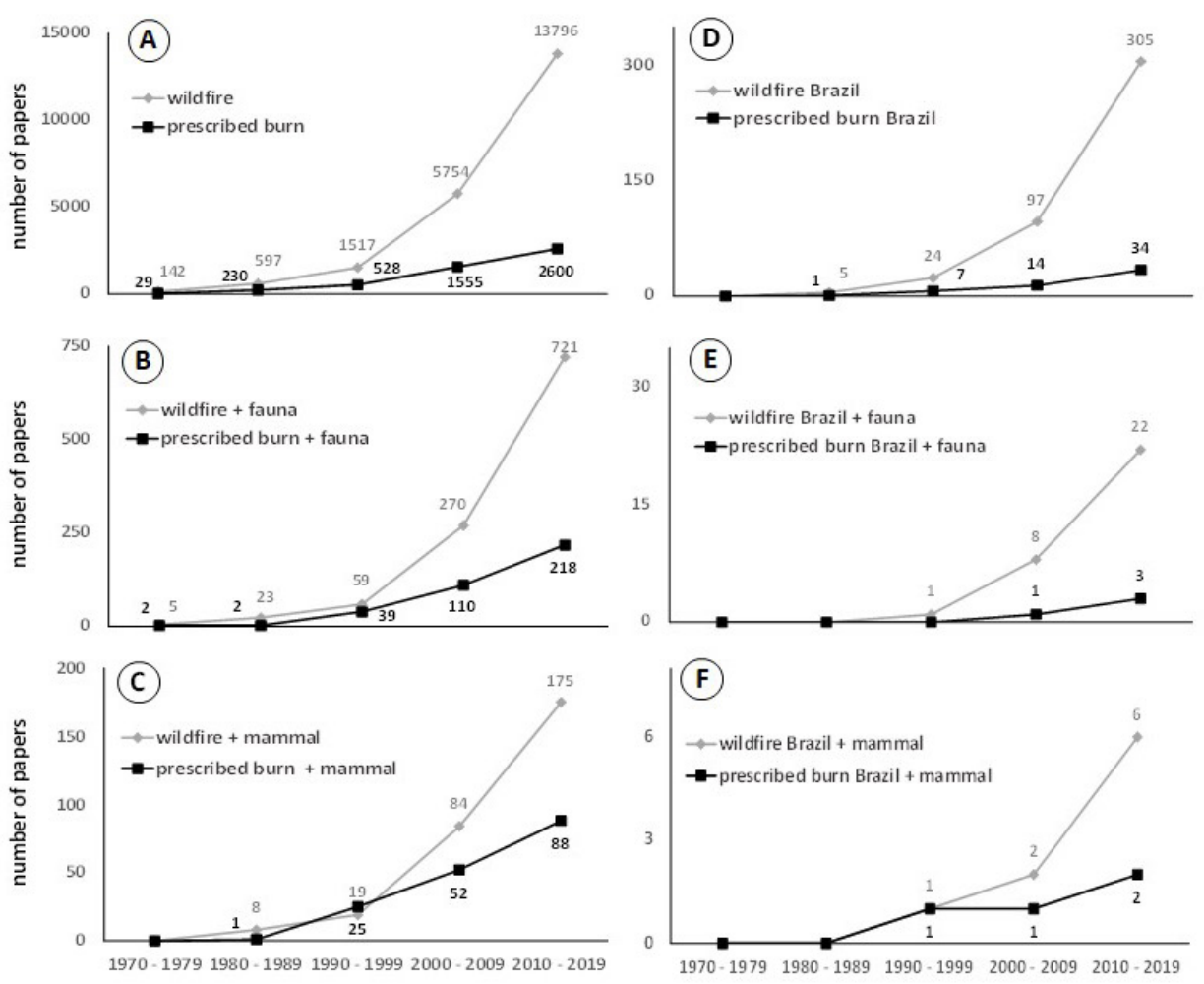

Figure 4. Historic number of papers since 1970 to 2019, divided by decades, comparing the published (A) Wildfire and Prescribed Burn, (B) Wildfire + Fauna and Prescribed Burn + Fauna, (C) Wildfire + Mammal and Prescribed Burn + Mammal, (D) Wildfire Brazil and Prescribed Burn Brazil, (E) Wildfire Brazil + Fauna and Prescribed Burn Brazil + Fauna and (F) Wildfire Brazil + Mammal and Prescribed Burn Brazil + Mammal

followed by Cerrado, Amazon Forest, Caatinga, Atlantic Forest and Pampa. The geographic distribution of 961 papers with fire research in Brazil seems to be unrelated to the average number of hotspots (Table 2).

The Scopus search returned only nine papers for the terms Wildfire Brazil + Mammal. Three papers were about small mammals and six dealt with mid-sized to large mammals. For the terms Prescribed Burn Brazil + Mammal we found only four papers, all dealing with small mammals.

\section{Discussion}

Fire research has been conducted on all continents. NA and EU dominate most (70\%) of all global research related to fire management. USA and AUS stand out as protagonists in their continents and with the largest papers number in comparison to other countries. The dominance of these countries in total number of papers (USA: $34 \%$ and AUS: $9 \%$ ) is related to the historical knowledge of original peoples and their relationship with fire. In these countries the knowledge of use of controlled fire by indigenous and aboriginal people was valued and absorbed by European colonists (Johnson \& Hale 2002, Morgan et al. 2020).

The volume of research is related to investment in $R \& D$ (Figure 2) and to the occurrence of fires, measured as the number of hotspots in each country (Figure 3). The dominance of NA in the number of papers is probably related to high investment of the USA and Canada in R\&D and their historical tradition in science and technology. Similarly, the EU, the next continent in the number of papers, has several countries that invest heavily in research, such as ESP and GBR. The third continent is AS with CHN as the main country and the second with the largest investments in R\&D. However, the correlation between investment and number of papers was weak as not all countries invest proportionately in research related to wildfire. $\mathrm{CHN}$ is the country with the largest number of hotspots in Asia (Figure 3) but when considering the territory's size, fire becomes relatively less important than in other countries, suggesting that the subject is not so relevant for investments in R\&D (Figure 2).

Another factor that may explain why some countries lead fire research at the global or continental level is the occurrence of fire. We found that the leading countries in fire research at each continent (CHI, USA, AUS and BRA) are also those with more hotspots (Figure 3). MODIS hotspots have been widely used to study the occurrence of fire on a global scale as they provide highly relevant information about fire events, their spatial and seasonal trends, allowing comparisons. However, they do not necessarily reflect wildfire sizes, as the relationships between active fires and burnt areas are not constant in space and time (Hantson et al. 2013). The proportion of publications relating fires to fauna in general or to mammals in particular are insignificant. This indicates a large gap in the knowledge of responses to fire by the fauna and mammal. This is even more evident when we consider papers from the last 50 years (Figure 4B, 4C).

As for temporal trends in publication rates (Figure 5A, 5B) we observed that the slope for Wildfire is 7.5 times higher than for Prescribed Burn and rates for Wildfire increased eighteen times more than the term Wildfire + Fauna. This reveals a low research interest in Prescribed Burn or in responses of fauna and mammals to fire. However, we note that the dominance of the term Wildfire in search returns may be due to the fact that the other terms are sub-topics in Wildfire subject. 

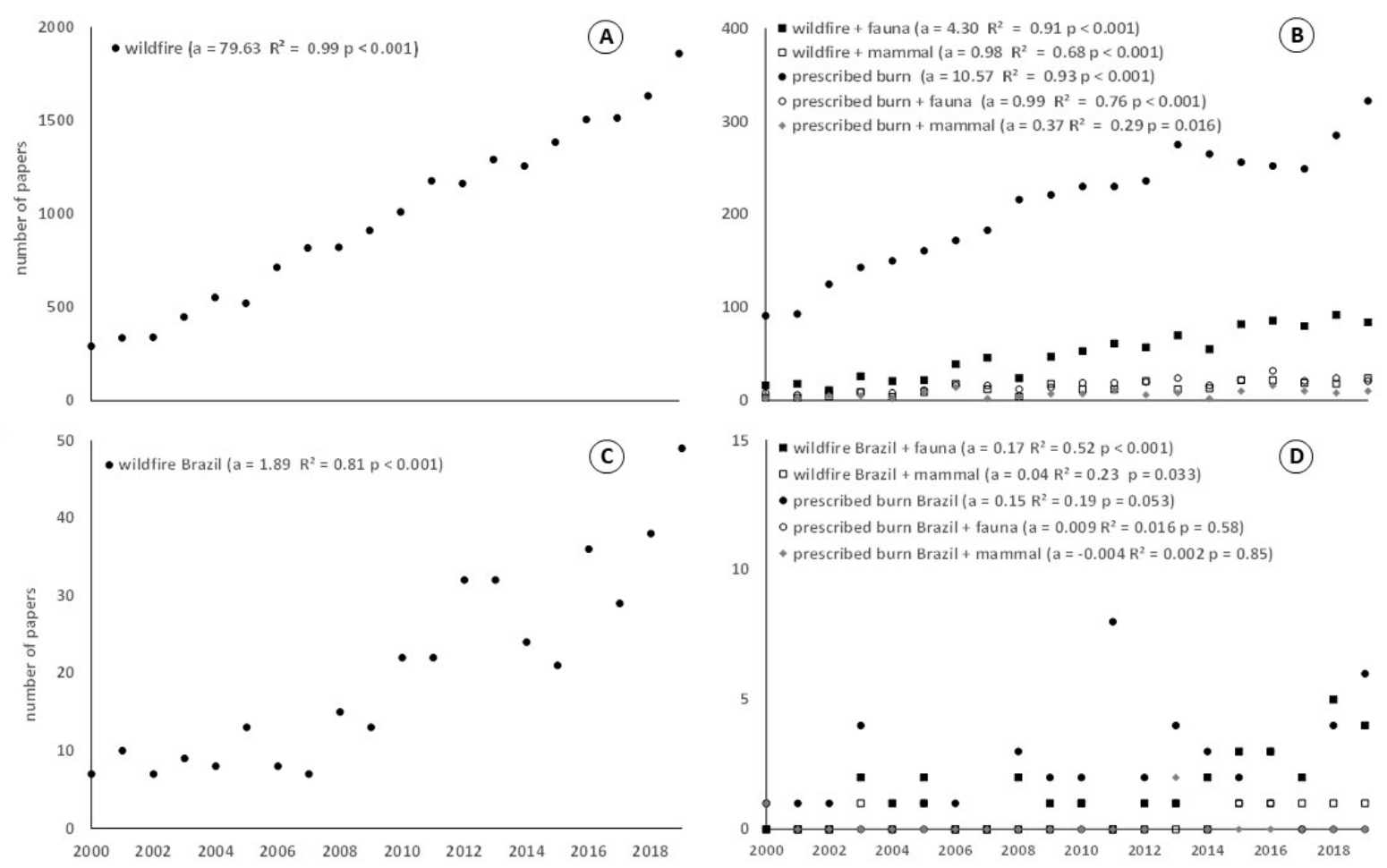

Figure 5. Scatter plot of number of papers between 2000 and 2019 in World: (A) Widfire; (B) Widfire + Fauna, Widfire + Mammal, Prescribed Burn, Prescribed Burn + Fauna, Prescribed Burn + Mammal; and in Brazil: (C) Widfire; (D) Widfire + Fauna, Widfire + Mammal, Prescribed Burn, Prescribed Burn + Fauna, Prescribed Burn + Mammal (a: slope, $\mathrm{R}^{2}$ : coefficient of determination, p: significance probability). The degree of freedom is one for linear regressions

Table 2. Distribution of average of hotspots and number of papers for different search terms by Brazilian Biomes. (Source: INPE and SCOPUS)

\begin{tabular}{|c|c|c|c|c|}
\hline Brazilian Biomes & Hotspots / km2 & Fire & Fire + Fauna & Fire + Mammal \\
\hline Pantanal & 0,041 & 35 & 6 & 1 \\
\hline Cerrado & 0,037 & 529 & 57 & 22 \\
\hline Caatinga & 0,023 & 64 & 8 & 1 \\
\hline Atlantic Forest & 0,018 & 141 & 40 & 12 \\
\hline
\end{tabular}

The priority that was given to wildfires in detriment to prescribed burn probably derives from the severe social and economic impacts of the former, which includes loss of human lives, and damage to property and crops (Stephenson et al. 2013). This is understandable since a better understanding of behavior of uncontrolled and dangerous fire is a necessary first step for planning and executing preventive actions, especially with the use of fire. This also partially explains why research on prescribed burn only started to appear later. Studies on prescribed burn are still in their infancy. A better understanding of role of prescribed burns in fire control and wildlife management are urgently needed to guide actions to minimize the negative impacts of wildfires and favor fire as an ecological factor.

Wildfires are an important issue at global level, and their importance tends to increase as the global climate changes (Anderegg et al. 2020). Although research on wildfires in general has been increasing consistently, the same cannot be said about research on prescribed burns and faunal and mammal responses to fires. These research areas demonstrate a large gap in knowledge and need incentive.
The scenario is similar in Brazil, with proportionally fewer papers relating fire to fauna and mammals. This highlights the urgent need for further studies on mammal responses to fire, especially considering that the country is a megadiverse country and the second in diversity of the mammals with 678 terrestrial species, of which 102 are officially classified as threatened (ICMBio/MMA 2018a).

The Brazilian red list of endangered species aims to guide prevention, conservation, and management to minimize threats and risks for endangered wildlife. This list is also a tool to understand the conservation status of biodiversity and define priorities for public policies regarding conservation and use of natural resources (ICMBio/ MMA 2018b). We believe that a sound knowledge of the sensitivity of wildlife species to fires is paramount to effective conservation action. The growth rate of publication in Wildfire in Brazil was 42 times lower than global rate, and Prescribed Burn publications remained stagnant. This demonstrates the large knowledge gap in Brazilian research on these issues and emphasizes the need for more investment in this field. The need for more research relating fire ecology and mammals can be 
illustrated by the diverging results reported by different studies on rodent responses to fire. A study on the effects of fire on Necromys lasiurus found negative effects (Vieira 1999), other reported no effects (Layme et al. 2004) and yet other found that the species benefited from fires (Briani et al. 2004). This indicates that the available data is still incipient and represents limited spatial and temporal scales (Frizzo et al. 2011). For example, some researchers, such as Briani et al. (2004), argue that in the Cerrado the ability of small mammals to cope with fires and the great dissimilarity among post-burning seral stages suggest that a mosaic of areas representing different post-fire seral stages could increase the regional diversity of this group. There is no unified understanding of how fire may influence vertebrate diversity and how fire influences vegetative structure and subsequently, food resources that wildlife rely on (Darracq 2016).

In Brazil, more than half of all research related to fire has been conducted in Cerrado, maybe because of predominance of pyrophyte savanna physiognomies in the Biome. Nevertheless, other Biomes also demand attention as they are also subject to wildfires, especially the Pantanal, a fire-dependent Biome too, with highest hotspot average but smallest number of papers. The Amazon comes next with a particularly high concentration of hotspots in its southern portion, known as the "Arc of deforestation" (Brando et al. 2020).

In the last 50 years, only 166 papers relating Fauna and Wildfire have been published for any Biome in Brazil. For mammals, the number is even lower with only 45 papers. The Caatinga and Pantanal Biomes score a single publication each. Borges et al. (2015) and Arruda et al (2018) found that only $8 \%$ of all papers about Cerrado fires referred to mammals. Frizzo et al. (2011) found that only 20 out of 1,512 fire papers $(<1 \%)$ were related to fauna. Arruda et al. (2018) did not found any temporal trend in the number of scientific publications relating mammals and fire in Cerrado.

The growing interest in the effects of fire in Cerrado may be due to the biome complexity: both high and low frequencies of fire can have negative effects on biodiversity (Maravalhas \& Vasconcelos 2014; Anjos et al. 2016), and proper fire management programs based on scientific knowledge are still in development (Durigan \& Ratter 2016). In Brazil, there is a pressing need for fire policies to conserve Cerrado (Durigan $\&$ Ratter 2016). A better knowledge about the effects of fire on different taxa and regions of the biome may help to create sound guidelines for fire management policies (Arruda et al. 2018). This analysis for Cerrado extends to other Biomes as well. We understand that fire management should cover a range of actions from fire exclusion in sensitive areas to prescribed burn in pyrophytic environments or to favor endangered species, going through the use of fire to protect sensitive environments and standardizing the use of fire for farming.

The Brazilian National Congress in currently discussing a federal bill aiming the Integrated Fire Management (Federal Bill 11276/2018 www.camara.leg.br/proposicoesWeb/prop_mostrarintegra?codteor= 1703491 \&filename $=$ Tramitacao-PL $+11276 / 2018)$. The bill aims to propose instruments for analyzing the impacts of fires and integrated fire management on land use change, ecosystem conservation, public health, flora, fauna, and climate change. If approved, this Law will assist implementation of prevent and fight wildfire activities by integrating private sector with federal and state-level infrastructure and actions, improving the biodiversity and natural resources conservation. We believe that this law may encourage the financing and targeting of research projects related to fire ecology and biodiversity conservation. We still lack an unified understanding of how fires directly or indirectly influence fauna diversity and how this in turn affects their conservation and the ecosystem services they provide. This information is essential to establish sound conservation policies in a changing world.

\section{Acknowledgements}

We would like to thank the team of the Fire Monitoring Portal (INPE) for the support in raising hotspots, and Camila Niel Berlinck for the support with the translation.

\section{Author Contributions}

Christian Niel Berlinck: contribution in the concept and design of the study; contribution to data collection; contribution to data analysis and interpretation; contribution to manuscript preparation; contribution to critical revision.

Luanne Helena Augusto Lima: contribution in the concept and design of the study; contribution to data collection; contribution to data analysis and interpretation; contribution to manuscript preparation; contribution to critical revision

Elildo Alves Ribeiro de Carvalho Junior: contribution to data analysis and interpretation; contribution to manuscript preparation; contribution to critical revision.

\section{Conflicts of Interest}

The authors declare that they have no conflict of interest related to the publication of this manuscript.

\section{References}

ANDEREGG, W.R.L., TRUGMAN, A.T., BADGLEY, G., ANDERSON, C.M., BARTUSKA, A., CIAIS. P., CULLENWARD, D., FIELD, C.B., FREEMAN, J., GOETZ, S.J., HICKE, J.A., HUNTZINGER, D., JACKSON, R.B., NICKERSON, J., PACALA, S., RANDERSON, J.T. 2020. Climate-driven risks to the climate mitigation potential of forests. Science. 368:eaaz7005.

ANJOS, D., ALVES-SILVA, E., RIBEIRO, S.P. 2016. Do fire and seasonality affect the establishment and colonisation of litter arthropods? Journal of Insect Conservation. 20:653-661.

ANONYMOUS. 1894. The forest fires. Journal of The American Medical Association. XXIII(10):395.

ANONYMOUS. 1989. Decree No 97635 of 10 April 1989 regulating Article 27 of the Forest Code and relating to the prevention and combat of forest fires, and other matters. Annual Review of Population Law. 16:213.

ARRUDA, F.V., SOUSA, D.G., TERESA, F.B., PRADO, V.H.M., CUNHA, H.F., IZZO, T.J. 2018. Trends and gaps of the scientific literature about the effects of fire on Brazilian Cerrado. Biota Neotropica. 18(1):e20170426.

ARRUDA, R.V., IZZO, T.J., TERESA, F.B., CAMAROTA, F. 2020. Different burning intensities affect cavity utilization patterns by arboreal ants in a tropical savanna canopy. Ecological Indicators. 116:106493

BATISTA, E.K.L., RUSSELL-SMITH, J., FRANÇA, H., FIGUEIRA, J.E.C. 2018. An evaluation of contemporary savanna fire regimes in the Canastra National Park, Brazil: Outcomes of fire suppression policies. Journal of Environmental Management. 205:40-49.

BORGES, P.P., OLIVEIRA, K.A.F.A., MACHADO, K.B., VAZ, U.L., CUNHA, H.F., NABOUT, J.C. 2015.Trends and gaps of the scientific literature on the Cerrado biome: A scientometric analysis. Neotropical Biology and Conservation. 10(1):2-8. 
BOWMAN, D.M.J.S., BALCH, J.K., ARTAXO, P., BOND, W.J., CARLSON, J.M., COCHRANE, M.A., D'ANTONIO, C.M., DEFRIES, R.S., DOYLE, J.C., HARRISON, S.P. 2009. Fire in the Earth system. Science. 324:481-484.

BRANDO, P., MACEDO, M., SILVÉRIO, D., RATTIS, L., PAOLUCCI, L., ALENCAR, A., COE, M., AMORIM, C. 2020. Amazon wildfires: Scenes from a foreseeable disaster. Flora: Morphology, Distribution, Functional Ecology of Plants. 268:151609.

BRIANI, D.C., PALMA, A.R.T., VIEIRA, E.M., HENRIQUES, R.P.B. 2004. Post-fire succession of small mammals in the Cerrado of central Brazil. Biodiversity and Conservation. 13:1023-1037.

BRIANI, D.C. \& VIEIRA, E.M. 2006. Efeito do Fogo em Mamíferos do Brasil. In Mamíferos do Brasil: genética, sistemática, ecologia e conservação (T.R.O. Freitas, E.M Vieira, S.M. Pacheco, A.U. Christoff, eds). Sociedade Brasileira de Genetica, Ribeirao Preto, p. 41-54.

CARDINALE, B.J., DUFFY, J.E., GONZALEZ, A., HOOPER, D.U., PERRINGS, C., VENAIL, P., NARWANI, A., MACE, G.M., TILMAN, D., WARDLE, D.A., KINZIG, A.P., DAILY, G.C., LOREAU, M., GRACE, J.B., LARIGAUDERIE, A., SRIVASTAVA, D.S., NAEEM, S. 2012. Biodiversity loss and its impact on humanity. Nature. 486:59-67.

DARRACQ, A.K., BOONE IV, W.W., MSCLEERY, R.A. 2016. Burn regime matters: a review of the effects of prescribed fire on vertebrates in the longleaf pine ecosystem. Forest Ecology and Mangement. 378:214-221.

DAVIDSON, A.D., DETLING, J.K., BROWN, J.H. 2012. Ecological roles and conservation challenges of social, burrowing, herbivorous mammals in the world's grasslands. Frontiers in Ecology and Evolution. 10:477-486.

DURIGAN, G. \& RATTER, J.A. 2016. The need for a consistent fire policy for Cerrado conservation. Journal of Applied Ecology. 53(1):11-15.

DURIGAN, G., PILON, N.A.L., ABREU, R.C.R., HOFFMANN, W.A., MARTINS, M., FIORILLO, B.F., ANTUNES, A.Z., CARMIGNOTTO, A.P., MARAVALHAS, J.B., VIEIRA, J. 2020. No Net Loss of Species Diversity After Prescribed Fires in the Brazilian Savanna. Frontiers in Forests and Global Change. 3:13.

FISHER, W.R. 1894. New French law for the prevention of forest fires. Nature. 49(1262):233-234.

FRIZZO, T.L.M., BONIZÁRIO, C., BORGES, M.P., VASCONCELOS, H.L. 2011. Revisão dos Efeitos do Fogo Sobre a Fauna de Formações Savânicas do Brasil. Oecologia Australis. 15(2): 365-379.

HANTSON, S., PADILLA, M., CORTI, D., CHUVUECO, E. 2013. Strengths and weaknesses of MODIS hotspots to characterize global fire occurrence. Remote Sensing of Environment. 131:152-159.

HARDESTY, J., MYERS, R., FULKS, W. 2005. Fire, ecosystems, and people: a preliminary assessment of fire as a global conservation issue. The George Wright Forum. 22:78-87.

HARPER, A.R., DOERR, S.H., SANTIN, C., FROYD, C.A., SINNADURAI, P. 2018. Prescribed fire and its impacts on ecossystem services in the UK. Science for the Total Environmental. 624:691-703.

HE, T., LAMONT, B.B., PAUSAS, J.G. 2019. Fire as a key driver of Earth's biodiversity. Biological Reviews. 94:1983-2010

HENRY, N.B. \& FLORENCE, R.G. 1966. Establishment and development of regeneration in spotted gum-ironbark forests. Australian Forestry. 30(4):304-316

ICMBio/MMA. 2018a. Livro Vermelho da Fauna Brasileira Ameaçada de Extinção Brasília:ICMBio v.1

ICMBio/MMA. 2018b. Livro Vermelho da Fauna Brasileira Ameaçada de Extinção Brasília: ICMBio v.2

INPE. 2020. Portal do Monitoramento deQueimadas eIncêndios [cited2020 May21] Available: http://www.inpe.br/queimadas

JOLLY, W.M., COCHRANE, M.A., FREEBORN, P.H., HOLDEN, Z.A., BROWN, T.J., WILLIAMSON, G.J., BOWMAN, D.M.J.S. 2015. Climateinduced variations in global wildfire danger from 1979 to 2013. Nature Communications. 6:7537.

JOHNSON,A.S. \& HALE, P.H. 2002. The Historical Foundations of Prescribed Burning for Wildlife: a Southeastern Perspective. In: USDA Forest Service The role of fire in nongame wildlife management and community restoration: traditional uses and new directions. Available: https://wwwfsusdagov/treesearch/pubs/3164
KEELY, J.E., PAUSAS, J.G., RUNDEL, P.W., BOND, W.J., BRADSTOCK, R.A. 2011. Fire as an evolutionary pressure shaping plant traits. Trends in Plant Science. 16(8):406-411.

KELLY, L.T., NIMMO, D.G., SPENCE-BAILEY, L.M., TAYLOR, R.S., WATSON, S.J., CLARKE, M.F., BENNETT, A.F. 2012. Managing fire mosaics for small mammal conservation: a landscape perspective. Journal of Applied Ecology. 49:412-421.

KIRCHHOFF, V.W.J.H. \& MARINHO, E.V.A. 1989. A survey of continental concentrations of atmospheric $\mathrm{CO}$ in the southern hemisphere. Atmospheric Environment. 23(2):461-466.

KOMAREK, E.V. 1969. Fire and animal behavior. In: Komarek EV (ed) Proceedings Tall Timbers Fire Ecology Conference: 9 Tall Timbers Fire Ecology Conference, 9 Tall Timbers Research Station, Tallahassee.

LAYME, V.M.G., LIMA, A.P., MAGNUSSON, W.E. 2004. Effects of fire, food availability and vegetation on the distribution of the rodent Bolomys lasiurus in an Amazonian savanna. Journal of Tropical Ecology. 20:183-187.

LESLIE, A.C.D. 1981. Aerosol emissions from forest and grassland burnings in the southern amazon basin and central Brazil. Nuclear Instruments and Methods. 1981;181(1-3):345-351.

MARAVALHAS, J. \& VASCONCELOS, H.L. 2014. Revisiting the pyrodiversity- biodiversity hypothesis: long-term fire regimes and the structure of ant communities in a Neotropical savanna hotspot. Journal of Applied Ecology. 51:1661-1668.

MCARTHUR, A.G. 1966. Prescribed burning in australian fire control. Australian Forestry. 30(1):4-11.

MORGAN, G.W., TOLHURST, K.G., POYNTER, M.W., COOPER, N., MCGUFFOG, T., RYAN, T., WOUTERS, M.A., STEPHANS, N., BLACK, P., SHEEHAN, D., LEESON, P., WHIGHT, S., DAVEY, S.M. 2020. Prescribed burning in south-eastern Australia: history and future directions. Australian Forestry. 83(1):4-28.

MIRANDA, A.C., MIRANDA, H.S., DE FÁTIMA OLIVEIRA DIAS, I., DE SOUZA DIAS, B.F. 1993. Soil and air temperatures during prescribed cerrado fires in Central Brazil. Journal of Tropical Ecology. 9(3):313-320.

MISTRY, J. 1998a. Corticolous lichens as potential bioindicators of fire history: A study in the cerrado of the Distrito Federal, central Brazil. Journal of Biogeography. 25(3):409-441.

MISTRY, J. 1998b. Fire in the cerrado (savannas) of Brazil: an ecological review. Progress in Physical Geography. 22(4):425-448.

MYERS, R.L. 2006. Living with Fire: Sustaining Ecosystems \& Livelihoods Through Integrated Fire Management. The Nature Conservancy, Global Fire Initiative.

PASTRO, L.A., DICKMAN, C.R., LETNIC, M. 2011. Burning for biodiversity or burning biodiversity? Prescribed burn vs. Wildfire impacts on plants, lizards and mammals. Ecological Applications. 21(8):3238-3253.

PIVELLO, V.R. \& COUTINHO, L.M. 1992. Transfer of macro-nutrients to the atmosphere during experimental burnings in an open cerrado (Brazilian savanna). Journal of Tropical Ecology. 8(4):487-497.

PIVELLO, V.R., NORTON, G.A. 1996. FIRETOOL: An expert system for the use of prescribed fires in Brazilian savannas. Journal of Applied Ecology. 33(2):348-356.

PIVELLO, V.R. 2011. The use of fire in the Cerrado and Amazonian Rainforest of Brazil: Past and Present Fire. Ecology. 7(1):24-39.

PRINS, E.M., FELTZ, J.M., MENZEL, W.P., WARD, D.E. 1998. An overview of GOES-8 diurnal fire and smoke results for SCAR-B and 1995 fire season in South America. Journal of Geophysical Research Atmospheres. 103(D24):31821-31835.

RATTO, F., SIMMONS, B.I., SPAKE, R., ZAMORA-GUTIERREZ, V., MACDONALD, M.A., MERRIMAN, J.C., TREMLETT, C.J., POPPY, G.M., PEH KS-H, DICKS, L.V. 2018. Global importance of vertebrate pollinators for plant reproductive success: a meta-analysis. Frontiers in Ecology and the Environment. 16(2):82-90.

RIPPLE, W.J., ESTES, J.A., BESCHTA, R.L., WILMERS, C.C., RITCHIE, E.G., HEBBLEWHITE, M., BERGER, J., ELMHAGEN, B., LETNIC, M., NELSON, M.P., SCHMITZ, O.J., SMITH, D.W., WALLACH, A.D., WIRSING, A.J. 2014. Status and Ecological Effects of the World's. Largest Carnivores Science. 343:1241484. 
SANTÍN, C. \& DOERR, S.H. 2016. Fire effects on soils: the human dimension. Philosophical Transactions of the Royal Society B: Biological Sciences. 371:20150171.

SANTOS, X., BADIANE, A., MATOS, C. 2016. Contrasts in short- and longterm responses of Mediterranean reptile species to fire and habitat structure. Oecologia.180:205-216.

SARASOLA, J.H., ZANÓN-MARTÍNEZ, J.I., COSTÁN, A.S., RIPPLE, W.J. 2016. Hypercarnivorous apex predator could provide ecosystem services by dispersing seeds. Scientific Reports. 6:1-6.

SMITH, J.K. 2000. Wildland fire in ecosystems: effects of fire on fauna. US Department of Agriculture, Forest Service, Rocky Mountain Research Station.

STEPHENSON, C., HANDMER, J., BETTS, R. 2013. Estimating the economic, social and environmental impacts of wildfires in Australia. Environmental Hazards. 12(2):93-111.

TORRES, D.A., CASTAÑO, J.H., CARRANZA-QUICENO, J.A. 2020. Global patterns in seed germination after ingestion by mammals. Mammal Review. 50:3.

UHL, C. \& BUSCHBACHER, R. 1985. A disturbing synergism between cattle ranch burning practices and selective tree harvesting in the eastern Amazon. Biotropica. 17(4):265-268.
UNESCO. 2020. Available: http://uisunescoorg/apps/visualisations/researchand-development-spending/

VIEIRA, E.M. 1999. Small mammal communities and fire in the Brazilian Cerrado. Journal of Zoology. 249(1):75-81.

VILLAR, N., PAZ, C., ZIPPARRO, V., NAZARETH S., BULASCOSCHI L., BAKKER E.S., GALETTI M. 2020. Frugivory underpins the nitrogen cycle. Functional Ecology. 00:1-12.

VILLARREAL, D., CLARK, K.L., BRANCH, L.C., HIERRO, J.L., MACHICOTE, M. 2008. Alteration of ecosystem structure by a burrowing herbivore, the plains vizcacha (Lagostomus maximus). Journal of Mammalogy. 89:700-711.

WHELAN, R.J. 1997. Ecology of fire UK: Cambridge University, 2nd press.

YARNELL, R.W., SCOTT, D.M., CHIMIMBA, C.T., METCALFE, D.J. 2007. Untangling the roles of fire, grazing and rainfall on small mammal communities in grassland ecosystems. Oecologia. 154:387-402.

Received: 05/10/2020

Revised: 28/04/2021

Accepted: 04/05/2021

Published online: 21/05/2021 